\title{
A katonai fittség átfogó értelmezése a Total Force Fitness program alapján
}

\section{Dr. Eleki Zoltán ezredes, PhD}

Kulcsszavak: fizikai fittség, komplex katonai fittség, egyéni harckészség

\begin{abstract}
A Magyar Honvédség számára fontos, hogy a társadalom romló fizikai és egészségi állapota ellenére folyamatosan rendelkezésre álljon a megfelelő létszámú, felkészített és motivált személyi állomány. A katonák kiválasztásában, a felkészítés tervezésében és végrehajtásában szerepet játszó szakembereknek helyesen kell értelmezni a katonai fittséget. Annak érdekében, hogy a katona testileg és mentálisan is egészséges (well-being), felkészült (readiness) és ellenálló (resilience), egyszóval fitt legyen, a fittséget olyan összetett tulajdonságként kell értelmezni, ami túlmutat az egészségi, pszichológiai és fizikai fittségen. A cikk célja, hogy az amerikai hadsereg Total Force Fitness elnevezésü programját bemutatva megalapozza és erősítse ezt a szemléletmódot.
\end{abstract}

Egy hadsereg értékét nagyban befolyásolja, hogy rendelkezésre áll-e a kellő számú és felkészültségű személyi állomány. A szükséges létszám záloga a hatékony toborzás és a megfelelő szervezeti megtartó erő, míg a minőséget a kiképzési és felkészítési programok határozzák meg. A kiképzés sikerének alapja, hogy a katona testi egészsége, fizikai és pszichés állapota megfelelő legyen. Ezen tulajdonságok pedig nagyban függnek a katona életmódjától, környezetétől és magánéletétől.

A kiválasztás, a kiképzés és felkészítés célja, hogy a katona egyéni harckészsége megfeleljen a katonai szolgálat és a fegy- veres harc kihívásainak, amit a katonai fittség fogalmával lehet a legtalálóbban jellemezni.

Írásomban megvizsgálom a katonai fittség fogalmát, és az azt befolyásoló körülményeket. A vizsgálathoz felhasználom az amerikai hadseregben 2010-ben készült tanulmánykötetet, amelyet Total Force Fitness (TFF) [Military Medicine, Volume 175,2010$]^{1}$ címmel közöltek, és amely szintén a katonai fittség összetettségét hangsúlyozza. Célom annak a szemléletnek az erősítése, miszerint a katonai fittséget egy olyan dinamikus egységként kell kezelni, ahol az egyes fittségi 
összetevők csak a többi alkotóelem függvényében értelmezhetők és fejleszthetők. Teszem mindezt a katonai testnevelö szerepében, a fizikai felkészítés szemszögéből vizsgálva a kérdést.

\section{A katonai fittség fogalma}

„Fittség alatt civil környezetben elsősorban a fizikai jólétet, egyfajta testi-lelki állapotot értünk. Katonai értelemben, mélyebben vizsgálva a fogalmat a fittség egy adott körülménynek, elvárásnak való megfelelést jelent. A háborúban a hadseregeknek és a katonáknak alkalmazkodni kell a harc összetettségéhez és káoszához, meg kell örizniük egészségüket, és a szolgálat befejezésével vissza kell illeszkedniük a civil társadalomba" [1].

Mullen tábornok a fittség fogalmából kiindulva átfogóan értelmezi és definiálja a katonai fittséget, beleértve minden olyan ismeretet, képességet és készséget, ami a harc káoszához való alkalmazkodást és az egészség megörzését lehetövé teszi. Az átfogó értelmezést részeire bontva a fogalom tovább finomítható. A fitt katona edzett és kiképzett, testileg és szellemileg felkészült a feladatokra, kiváló az egészségi állapota, ellenálló a szolgálattal járó fizikai és mentális hatásokkal szemben, és motivált a feladatok végrehajtására.

$\mathrm{Az}$ angolszász szakirodalomban az „individual combat readiness” kifejezés illik leginkább a katonai fittség fogalmához. Megállapítható, hogy teljeskörü egyetértés nem alakult ki a kutatók között a fogalmat illetően [2]. A meghatározásnál a legtöbbször olyan fogalmak jelennek meg, mint a csapatkohézió, fittség, kompetencia, állampolgári felelősség, morál, kötelességtudat, készenlét, formaidőzítés, hatékonyság, kiképzettség.
Castro szerint az egyéni harckészséget leginkább a családi állapot, a nem, az egészségi állapot, az alvásidő, az utolsó hét nap kiképzési terhelése és az egészségi állapotra vonatkozó saját benyomás határozza meg [3].

Caliber szerint az egyéni harckészség felkészültséget (training), képességeket (skill) és motivációt igényel [2].

Bolstad tovább bontja a fogalmat, amely olyan pszichológiai és szociológiai ismereteket és képességeket, valamint személyes beállítódást (attitüd) jelent, amely biztosítja, hogy a katona kompetens, professzionális formájával, testi és lelki jólétével meg tudjon felelni a dinamikusan változó harctér komplexitásának és kiszámíthatatlanságának [2].

\section{A katonai fittség átfogó értelmezése}

A katonai fittség legfontosabb összetevői az egészségi, pszichológiai és fizikai állapot, amit további tényezők befolyásolnak. A munkakörülmények, az egzisztenciális és családi háttér, a közösségi kapcsolatok pozitív és negatív változásai, a kiképzés-felkészítés, a tapasztalat és begyakorlottság, valamint a technikai és taktikai tudás. Ezek a tulajdonságok függnek attól a társadalmi és környezeti viszonyrendszertől, amelyben a katona él és tevékenykedik [1] (1. ábra).

Annak érdekében, hogy a harcos testileg és mentálisan is egészséges (wellbeing), felkészült (readiness) és ellenálló (resilience), egyszóval fitt legyen a feladatára, a család-szervezet-környezet hármas egységében kell értelmezni tevékenységét (1. ábra). Itt olyan tényezők jellemzik, mint a fizikai fittség, a pszichés állapot, a káros szenvedélyektől való mentesség, a testi egészség, a környezeti hatások, az egészséges táplálkozás, 


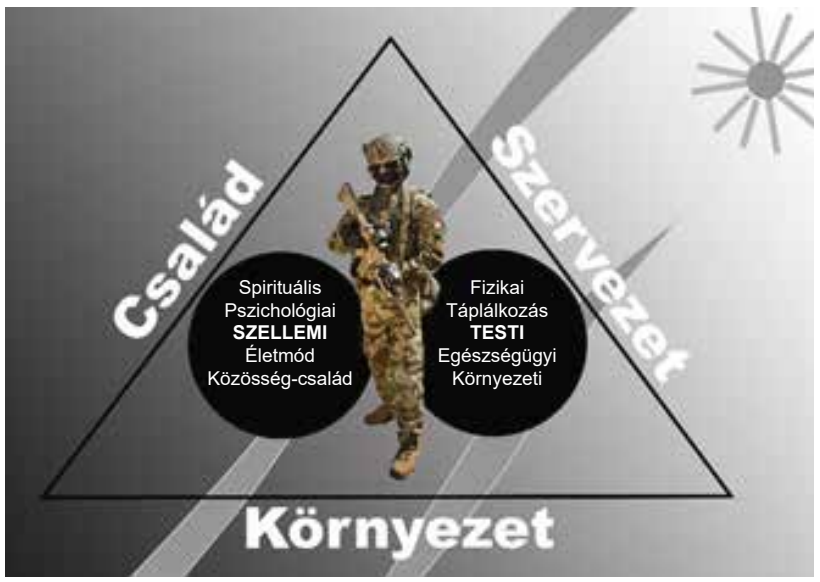

1. ábra. A katona a család-szervezet-környezet viszonyrendszerében [Military Medicine, 2010, 125. o.]

spirituális-vallási hatások, szociális-csoport hatások, vagy a családi kölcsönhatások.

A 2. ábrán a fenti tényezők részletesebb bontásban szerepelnek. A katonai fittség összetett rendszerében meghatározó, hogy az egyes rendszerelemek milyen hatást fejtenek ki egymásra (egymást támogató, semleges, vagy gátló) [1].

\section{A katonai fittség összetevőinek vizsgálata}

Fizikai fittség. A fizikai fittség fogalma a fizikai alkalmasság alapján határozható meg. Mindkét esetben valamilyen tevékenységhez, feladatvégrehajtáshoz szükséges fizikai adottságok és képességek, összességében a fizikai teljesítőképesség meglétét jelenti. Az árnyalatnyi különbség

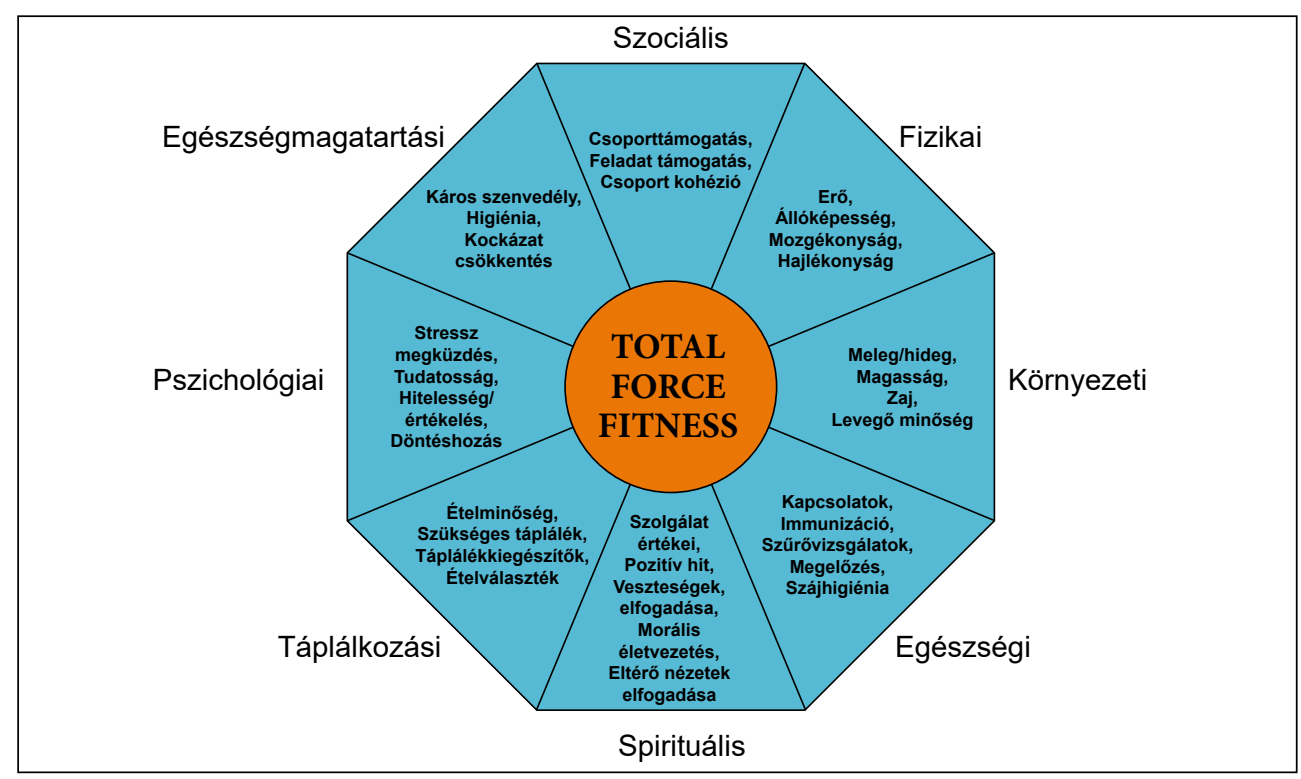

2. ábra. A TFF összetevői [Rounds, 2010, 125. o.] 


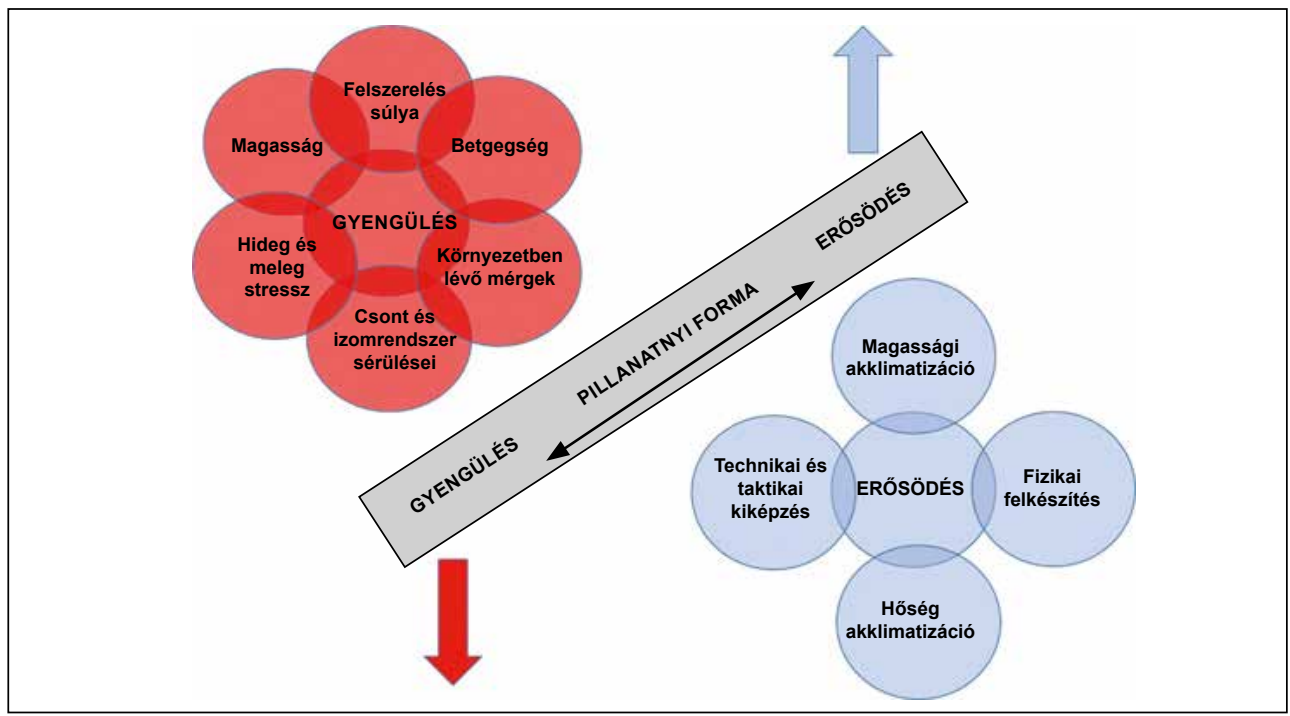

3. ábra. A pszichológiai fittséget befolyásoló tényezők [Bradley, 2016, 26. o.]

abban rejlik, hogy a fittség esetében már egy felkészítési folyamatra alapozott képességröl beszélünk, az alkalmasság esetében inkább a felkészítési folyamatban való részvételhez szükséges képességről.

Fontos a feladatok és küldetések fizikai összetevőinek a feltérképezése, ennek megfelelően a fizikai felkészítés programjának speciális, küldetés alapú meghatározása, a fittségi szint folyamatos monitorozása, a módszerek fejlesztése, valamint a nem megfelelö, esetleg káros edzésmódszerek és gyakorlatok kiszürése az egészségmegőrzés és a sérülések megelözése érdekében.

A TFF rendszerében vizsgálva evidencia, hogy a rendszeres minőségi testmozgás kedvező hatással van az egészségi állapotra. $\mathrm{Az}$ már kevésbé ismert, hogy a szociális egészségre, a depresszióra, a pánikbetegségre és az alvászavarra is jótékonyan hat, ezen túl segíthet a szenvedélybetegség leküzdésében, vagy az agresszió kezelésében is [4].

Pszichológiai fittség. A pszichológiai fittség egyfajta lelki egyensúly, illetve az egyensúlyt befolyásoló külső és belső hatások kivédését és kompenzációját biztosító állapot. A családon és a munkahelyi közösségen túl számos további szociális tér van, amely befolyásolja ezt a harmóniát. A katonák számára a harctéri stressz további terhelést jelent.

A modern kori hadviselés és az aszimmetrikus kihívások megjelenése új pszichológiai hatású nehézségek elé állítja a katonákat. Ilyen lehet az információ mennyiség és gyorsaság drasztikus növekedése, a túlzott és nehezen érthetö szabályok, a megnövekedett felelősség, a gyors és pontos döntéshozatali kényszer, valamint a katonai műveletekkel összefüggő egyéb nagy intenzitású hatások (fenyegetettség, tragédiák, stb.). A harctérre jellemző a komplexitás és a kiszámíthatatlanság (fog of war).

A katonák számára szükséges pszichológiai fittség felépítésének meghatározása érdekes és összetett feladat, amivel számos kutató foglalkozott. Az egyén lelki alkata, a stabil háttér és a pszichológiai felkészítések mellett fontos a beosztottak számára az elöljáró érezhető gon- 
doskodása, a különböző rendfokozatok közötti szinteket átfogó bizalom és érzelmi alapú kapcsok, valamint a katonák felkészítése a harc során jelentkező kihívásokra [5].

A pszichológiai fittséget negatívan és pozitívan befolyásoló tényezők hatását a Bradley és munkatársai által készített 3. ábra jól szemlélteti (2013.) [6].

Egészségmagatartás. Az egészségmagatartáshoz sorolhatók azok a magatartási normák, amelyek az életvezetést és az életmódot határozzák meg. A normák közül különösen érdekesek a káros szenvedélyekhez kapcsolódó attitűdök, mint a drog-, a dohány- és az alkoholfogyasztás mellözése, a katonák körében is népszerű súlycsökkentő, zsírégető, vagy éppen izomtömeg növelő táplálék kiegészítők, de ide sorolhatók a túlsúlylyal kapcsolatos problémák, az alvászavarok, vagy az olyan pszichoszociális problémák, mint a munkahelyi-, családi stressz, konfliktus, vagy egyéb társadalmi hatások.

Foglalkozás egészség. A foglalkozás egészséghez tartoznak azok a környezeti és társadalmi hatások, amelyek a ka- tonai szolgálattal összefüggésben jelentkeznek. Ezek lehetnek kémiai károsító hatások, mint például a kipufogó gázok, mérgek, sugárzó anyagok, biológiai hatások, mint a vírusok, baktériumok és paraziták. Lehetnek továbbá társadalmi hatások, úgy mint a családi-magánéleti, vagy munkahelyi problémák, amelyek a pszichés egészségre hatnak elsősorban, de azon keresztül a testi egészséget is befolyásolhatják pszichoszomatikus tünetként. Szintén a környezeti hatások közé tartoznak a harctéri stressz, a katasztrófák és balesetek során fellépő terhelések.

A felsorolt tényezők a fizikai felkészítés során is szerepet játszanak. A környezeti és társadalmi körülményeket a foglalkozások helyének, idejének és tartalmának megválasztásakor is figyelembe kell venni.

Egészségi és környezeti fittség. A két fogalmat a TFF együtt kezeli, mivel a környezeti hatások elsődleges szerepet játszanak az egészség alakulásában. Az egészség a modern felfogás szerint nem csak a betegség hiányát, hanem a teljes testi-lelki jólétet jelenti.

A környezeti fittség pedig a katona képességét jelenti arra, hogy bármilyen

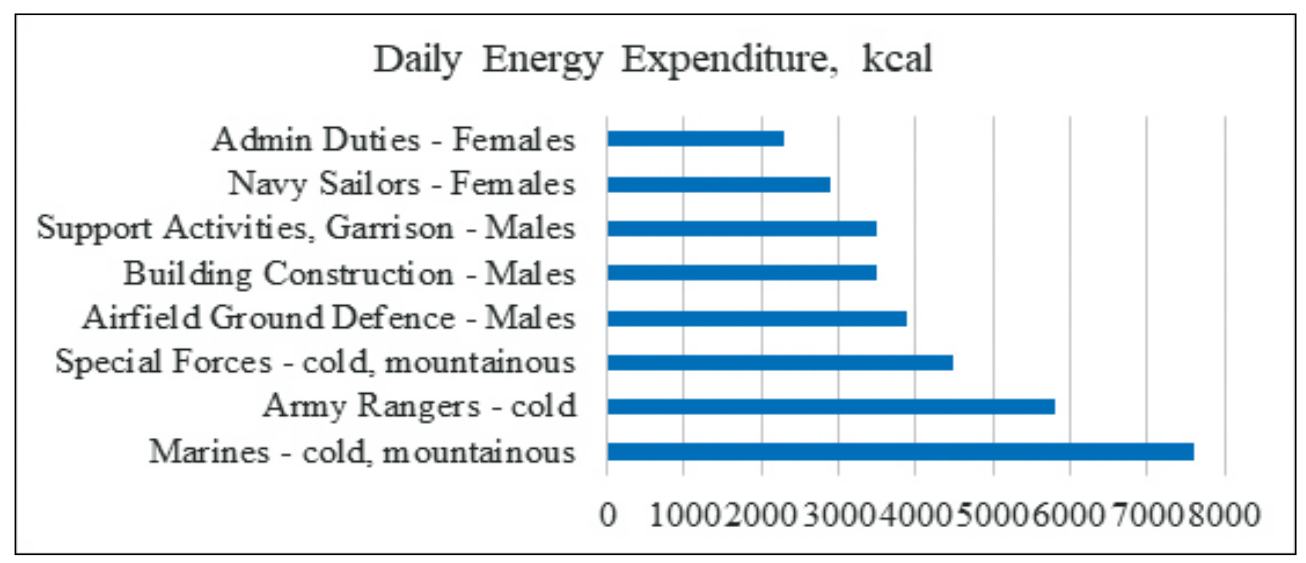

4. ábra. Átlagos napi kalória szükséglet az Amerikai Haderő egyes alegységeinél [Scott, 2010, 68. o.] 
környezetben (fizikai és társadalmi) képes legyen a sikeres tevékenységre. A fizikai környezeti hatások elsősorban a hőség, a hideg, a magasság, az ionizációs sugárzás, a zaj, a veszélyes anyagok, az allergiát okozó anyagok, vagy az élelemmel, vízzel, vagy más közvetítő anyaggal szállított biológiai ágensek. A társadalmi környezeti hatások vallási, faji, társadalmi különbségekből fakadó jellemzők, de ilyen lehet a média folyamatos jelenléte is.

Táplálkozással kapcsolatos fittség. A helyesen megválasztott étrend hozzájárul a testi egészséghez és a jó fizikai erőnléthez, segít a betegségek megelözésében. Fontos a megfelelő mennyiségü és minőségü táplálék bevitele (4. ábra) [1].

Más a napi kalória szükséglete egy ülő tevékenységet végzö embernek, mint annak, aki nehéz fizikai munkát végez (4. ábra). A túlzott kalória bevitel elhízáshoz és az ezzel járó metabolikus szindrómához, illetve betegséghez vezet.

Fontos a bevitt táplálék minősége és helyes aránya is, illetve szükség esetén a vitaminok, ásványi anyagok és nyomelemek pótlása. A napi folyadékszükségletet szintén biztosítani kell, lehetőleg kerülve a cukrozott, színezett üdítőket. Harci körülmények között külön nehézséget $\mathrm{okoz}$ a megfelelő időben és mértékben történő táplálék bevitel, különös tekintettel a folyadékpótlásra.

Spirituális fittség. A lelki-spirituális egészség szintén fontos összetevője a fittségnek. Spirituális és morális ellentétek akár fizikai, pszichikai, viselkedési problémákat is okozhatnak a katonák körében. Gondoljunk csak arra, hogy egy alegységen belül vallási felekezeti különbségek is okozhatnak belső feszültségeket, atrocitásokat. Ugyanakkor a vallásos hit számos előnnyel járhat a katonai fittség egészére nézve [1]. A spirituális fittség segíthet a traumák feldolgozásában, a vallási, etnikai különbségek tolerálásában, illetve a motiváció fenntartásában. Hufford kiemeli, hogy több kutatás számolt be arról, hogy a hívő katonák reménytelibbek és optimistábbak, kevésbé jellemző rájuk a depresszió, a

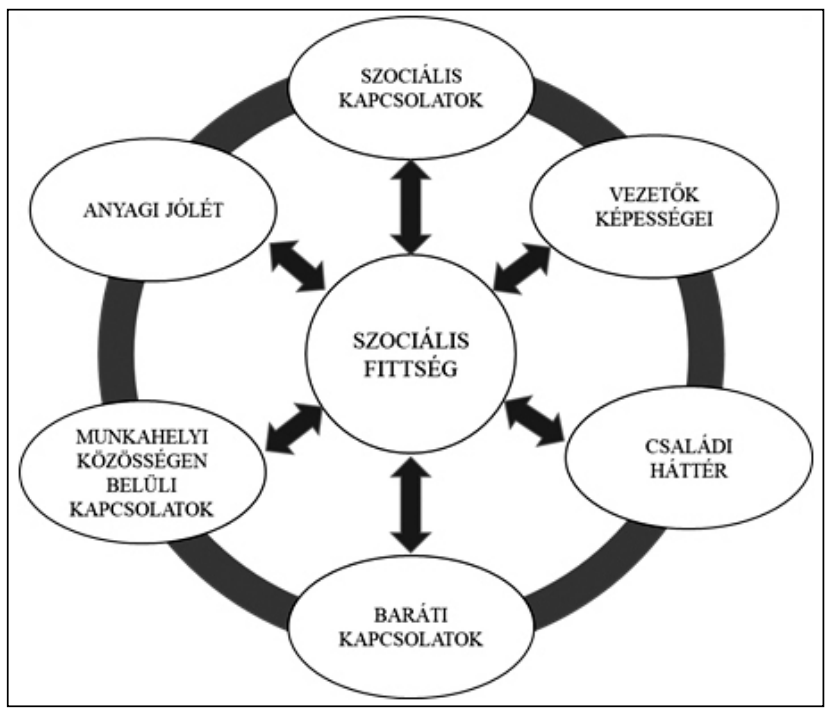

5. ábra. A szociális fittség rendszere [Military Medicine, 2010, 89. o.] 
nyugtalanság, a félelem, az öngyilkossági hajlam, az alkohol és drogfüggőség, stabilabb párkapcsolatban, kevésbé kockázatos életvitellel hosszabb életet élnek.

Szociális fittség. Minden emberre közvetlenül és közvetve is hat az a szociális tér, amelyben létezik. Az emberi kapcsolatok és a csoportkohézió meghatározó hatással van lelki egészségére, befolyásolja életmódját, tevékenységét. Egy öszszekovácsolt, jól működő csoport mindig erősebb és hatékonyabb az egyénnél, egyben támaszt és védelmet nyújt a tagjai számára (5. ábra) [1].

A katonai szolgálatra kiemelten jellemző, hogy a csoport tagja például átszervezés miatt egyik pillanatról a másikra kiszakadhat egy csoportból vagy harc során elveszítheti társát, társait. Gyakori az is, hogy a csoportra nagy hatást gyakorló vezető személyének a cseréje fejt ki negatív hatást. Mindez a csapategység gyengülésén keresztül kihat a csoport tagjaira (5. ábra).

Családi fittség. A katona, mint családapa, illetve családanya, vagy akár gyermek, fontos szerepet tölt be a család életében. A házastársi kapcsolat, a gyerekek felnevelése, gondozása fontos feladat, amelyre hatással van a szülö egészségi és lelki állapota. Egy PTSDben (Post Traumatic Stress Disease) szenvedő katona állapota kihat a családi környezetre is, felborítva a családi békét. Ugyanakkor a családjától távol lévő (gyakorlat, misszió, hadifogság) katona vágyódik párja és gyermekei után, akiknek a hiánya szintén befolyásolja lelki állapotát.

Ugyanilyen fontos a család támogató és toleráns hozzáállása. Minden katonának fontos, hogy bár sokat van távol a családjától, szerettei ezt megértsék, elfogadják, és a házastárs, vagy a szülő távolléte ne vezessen eltávolodáshoz, illetve a családi közösség felbomlásához.

\section{Összegzés}

Írásom középpontjába a katonai fittséget, az egyéni harckészség meghatározó elemét állítottam. Az amerikai Total Force Fitness rendszer elemzésével meg kívántam erősíteni azt a hazánkban is jellemző szakmai álláspontot, hogy ugyan a katonai fittség meghatározó elemei az egészségi, pszichológiai és fizikai fittség, de számos egyéb elemet is figyelembe kell venni, amelyek hatással vannak a fizikai fittségre és befolyásolják a katonai fittséget, illetve az egyéni harckészséget.

Ennek a szemléletnek a segítségével törekedni kell arra, hogy minden említett területen a lehetőségekhez mért legoptimálisabb körülmények vegyék körül a katonákat.

A testileg és szellemileg egészséges, fizikailag aktív életet élö, rendezett magánélettel bíró és munkakörnyezetébe harmonikusan illeszkedő katona hatással lesz bajtársaira és környezetére is, akik jó példát találhatnak benne. A fitt katonákból álló állomány pedig hatékonyabb szolgálatra képes, kevesebbet lesz távol munkahelyétől betegség miatt, nő a túlélő- és munkaképessége. A sportos, felkészült közösség pozitívan hat a Magyar Honvédség brandjének építésére is. Olyan hiteles képet jelenthet a társadalom számára, ami növeli a toborzó és megtartó erőt, és hosszabb távon, közvetetten az egész társadalom testi és lelki egészségére pozitív hatással lehet. 


\section{Irodalom}

[1] Total Force Fitness for the 21st Century. A New Paradigm, Military Medicine,, 2010, Vol. 175. https://www.researchgate.net/publication/278000131

[2] Barbara D. Adams: Military individual readiness, 2009, Department of National Defence Canada. 120 o.https://apps.dtic.mil/dtic/tr/ fulltext/u2/a514618.pdf

[3] Castro, C. A., Adler, A. B.: Working in the zone: Maintaining optimal readiness in U.S. soldiers. Paper presented at the 36th International Applied Military Psychology Symposium, Split, 2000. Croatia. 55. o. https://core.ac.uk/download/pdf/11039048. pdf

[4] DeMoor M.H.: Regular exercise, anxiety, depression and personality: a populationbased study. Preventiv Medicine 2006, 42: 273-279. DOI: 10.1016/j.ypmed.2005.12.002

[5] Bartone: Optimal leadership in small Army units, Handbook of military psychology. 1991, https://core.ac.uk/download/pdf/11039048. pdf

[6] Bradley C. Nindl.: State of the Science of Military Human Performance Optimization. State of the Science Symposia, 30 March 2016. http://herl.pitt.edu/symposia/fitnesshealth/presentations/Nindl-SotS-20160330. pdf

[7] Engelhard, I.M.,: Vulnerability associations and symptoms of post-traumatic stress disorder in soldiers. Figure 6. A Total Force Fitness Index. deployed to Iraq . Behav. Res. Ther., 2007, 45 (10): 2317- 25. https://www. ncbi.nlm.nih.gov/pubmed/17555708

[8] Field Manual, Army Physicals Readiness Training, 7-22.

[9] Péter L.: Depresszió és szív-érrendszeri betegségek összefüggései a katonanők vonatkozásában. Hadtudományi Szemle, 2016, 9 (1)

[10] Resperger I.: Aszimmetrikus hadviselés a modern korban. Zrínyi Kiadó, Budapest, 2015.

\section{Col. Z. Eleki PhD}

\section{The complex explanation of mili- tary fitness, based on the Total Force Fitness concept}

It is important for the Hungarian Defense Forces that despite the deteriorating physical and health conditions of the society, there will be a sufficient number of trained and motivated personnel. The professionals involved in the recruitment and training of the soldiers need to have a proper understanding of military fitness. In order to build the soldier's well-being, readiness and resilience, literally fit, fitness must be interpreted as a complex feature that goes beyond health, psychological and physical fitness. The article aims to establish and strengthen this approach by presenting the US Army's Total Force Fitness program.

Key-words: physical fitness, complexity of military fitness, individual combat readiness

Dr. Eleki Zoltán PhD 2000 Szentendre, Dózsa Gy. út 